Информация

\title{
КРАТКИЙ ОБЗОР ДИССЕРТАЦИЙ, ЗАЩИЩЕННЫХ В ДИССЕРТАЦИОННОМ СОВЕТЕ Д 212.253.05 В 2016 г.
}

Диссертационный совет Д 212.253.05 работал при ФГБОУ ВО «Сибирский государственный технологический университет», Красноярск.

В 2016 г. диссертационным советом было рассмотрено шесть кандидатских диссертаций по техническим наукам специальности 05.21 .03 - технология и оборудование химической переработки биомассы дерева; химия древесины.

Тематика рассмотренных советом диссертационных работ касается вопросов совершенствования технологии производства целлюлозы и бумаги, древесно-волокнистых плит, а также микробиологической переработки растительного сырья.

Диссертация Вдовиной О.С. «Поверхностная проклейка бумаги и картона синтезированным полимерным клеем» выполнена в области химии и технологии бумаги и картона.

На основании выполненных соискателем исследований разработаны рецептура нового полимерного клея «Ультрасайз SP 312» для поверхностной проклейки бумаги и картона, режим лабораторного и промышленного получения клея с заданными свойствами.

Предложены технические и технологические решения и рекомендации по эффективному применению клея «Ультрасайз SP 312», включающие в себя характеристики рабочих растворов клея и удельные расходы клея для промышленного применения, удовлетворяющие условиям проведения процесса проклейки в клеильных прессах погружного среднескоростного и пленочного высокоскоростного типов работ и позволяющие обеспечить высокоэффективную поверхностную проклейку. Доказана взаимосвязь мономерного состава клея «Ультрасайз SP 312» с его гидрофобными свойствами, высокая эффективность синтезированного клея для гидрофобизации и упрочнения поверхности бумаги и картона.

Результаты работы внедрены на предприятии ООО «СКИФ Спешиал Кемикалз» и ООО «Каменская БКФ», ожидаемый рассчитанный экономический эффект по данным опытно-промышленной выработки оценивается в 13-20 млн руб. при выпуске 100 тыс. т бумаги в год.

Работа выполнена в ФГАОУ ВО «Санкт-Петербургский государственный технологический университет растительных полимеров» и ООО «СКИФ Спешиал Кемикалз».

Две диссертационные работы выполнены в области исследования оборудования, машин и аппаратов химической технологии биомассы дерева.

В диссертации Шуркиной В.И. «Совершенствование ножевого размола волокнистых растительных полимеров в целлюлозно-бумажном производстве» разработана новая конструкция ножевой гарнитуры с криволинейной формой ножей для эффективного размола волокнистых полуфабрикатов с целью повышения эффективности процесса размола волокон и улучшения качественных показателей готовой продукции.

Предложена теория построения ножевой гарнитуры и определены основные технологические параметры процесса размола. Использование новой гарнитуры позволяет снизить укорочение исходной длины волокна и обеспечить необходимую степень обработки волокон, а также снизить удельные энергозатраты на проведение размола. Разработка размалывающей гарнитуры для дисковой мельницы запатентована.

Работа выполнена в Сибирском государственном технологическом университете.

В диссертации Марченко Р.А. разработан комплексный параметр эффективности безножевого размола волокнистых материалов, позволивший выявить качественно новые закономерности размола волокнистых полуфабрикатов при получении готовой продукции целлюлозно-бумажного производства.

Предложено теоретическое обоснование комплексного параметра эффективности процесса безножевого размола, включающего в себя конструктивные особенности приемного устройства, скоростных характеристик истечения струи волокнистой суспензии и скорости вращения подвижной преграды, с целью повышения эффективности процесса размола и улучшения качественных показателей готовой продукции.

Доказана перспективность обработки волокнистых полуфабрикатов на безножевой установке типа «струя-преграда» с вращающейся преградой с учетом комплексного параметра эффективности размола. 
Разработки запатентованы. Результаты работы внедрены в образовательные технологии для специальности «Технологии и оборудование целлюлозно-бумажного производства».

Работа выполнена в Сибирском государственном технологическом университете.

Диссертация Морозова И.М. «Подготовка и использование древесных отходов в производстве древесно-волокнистых плит» выполнена в области химии и технологии древесно-волокнистых, древесностружечных плит и пластиков.

Разработан способ подготовки древесно-волокнистых отходов в воздушной среде, выявлены качественно новые закономерности процесса подготовки вторичного древесного волокна; предложен нетрадиционный подход к способу подготовки древесно-волокнистых отходов в отсутствие высоких температур и давления, без использования воды и пара.

Определены основные технологические и конструктивные параметры размольной установки, работающей по сухому способу размола, влияющие на размерно-качественные, морфологические характеристики вторичных древесных волокон и физико-механические свойства готовых плит с учетом их использования в готовой плите. Создана размольная гарнитура, позволяющая эффективно подготавливать вторичные древесно-волокнистые полуфабрикаты в воздушной среде. Разработка запатентована.

Результаты работы приняты к внедрению на ОАО «Лесосибирский ЛДК № 1» и ЗАО «Новоенисейский ЛКХ».

Работа выполнена в Лесосибирском филиале Сибирского государственного технологического университета.

Две диссертации выполнены в области биохимии и микробиологической переработки растительного сырья.

Мельниковой Е.А. разработана технология переработки растительного сырья (березовые опилки, пшеничная солома) с получением белковых кормовых продуктов, основанная на микробиологической конверсии с использованием штамма гриба Pleurotus pulmonarius. На основе исследования закономерностей культивирования доказана высокая эффективность получения посевного материала для твердофазной ферментации растительных субстратов в условиях глубинно-твердофазного культивирования в присутствии частиц твердой фазы, при которых происходит иммобилизация мицелия на них, а также адаптация к используемому растительному субстрату.

Тарнопольской В.В. разработана технология микробиологической переработки древесных опилок и вегетативной части топинамбура с использованием культур Pleurotus ostreatus штамм PO-4.1 Pleurotus djamor штамм PD-3.2, отличающаяся введением стадии гидродинамической обработки растительного сырья при получении посевного материала для основной стадии твердофазной ферментации с получением кормовых продуктов, характеризующихся высоким содержанием белка (14-17 \%), включающего 40-45\% незаменимых аминокислот, и перевариваемостью не менее 50\%. Использование гидродинамической активации растительного сырья повышает степень конверсии сосновых опилок на 40\%, топинамбура на $20 \%$.

Обе работы выполнены в Сибирском государственном технологическом университете.

Все работы утверждены ВАК России, соискателям присуждена ученая степень кандидата наук.

В сентябре 2016 г. Сибирский государственный технологический университет вошел в состав опорного университета, созданного в г. Красноярске на базе Сибирского государственного аэрокосмического университета имени академика М.Ф. Решетнева.

В опорном университете приказом Минобрнауки России № 130/нк от 22.02.2017 создан совет по защите диссертаций на соискание ученой степени кандидата наук, на соискание ученой степени доктора наук Д 212.249.07.

Диссертационному совету разрешено принимать к защите диссертации по специальности 05.21.03технология и оборудование химической переработки биомассы дерева; химия древесины по химическим и техническим наукам.

Председатель диссертационного совета - Алашкевич Юрий Давыдович, доктор технических наук, профессор, член-корреспондент РАО, заведующий кафедрой «Машины и аппараты промышленных технологий», тел.: (391) 227-34-53.

Заместитель председателя диссертационного совета - Миронов Петр Викторович, доктор химических наук, профессор кафедры «Химическая технология древесины и биотехнология», тел.: (391) 227-36-54.

Ученый секретарь диссертационного совета - Исаева Елена Владимировна, доктор технических наук, профессор кафедры «Химическая технология древесины и биотехнология», тел.: (391) 227-36-54, e-mail: dissovetsibgtu01@mail.ru 